\title{
Effect of Different Host Plants on the Onion Thrips, Thrips tabaci Lind. and the Land Snail, Monacha spp. Population Abundance According to Intercropping some Vegetable Crops and the Final Yield Sanaa K. M. El-Fakharany \\ Plant Protection Research Institute ARC, Giza, Egypt
}

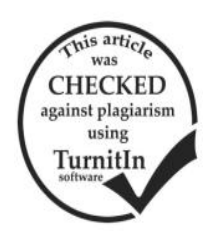

\section{ABSTRACT}

Field experiments were carried out at El-Riad district, Kafr El-Sheikh governorate during three successive seasons, 2014/15, 2015/16 and 2016/17. To study host preference and the effect of intercropping each of lettuce (Roman), onion (Buheirah red) and garlic (sids 40) cultivars, on the onion thrips, Thrips tabaci Lind. and the land snail, Monacha spp. population abundance and the resulting yield. T. tabaci was the high attractive to onion followed by garlic, while lettuce was least attractive during the three successive seasons. It can be noticed the highest monthly average number of $T$. tabaci were recorded in March on onion plantations alone and onion intercropping, with lettuce, followed by garlic plantations alone, garlic (intercropped with lettuce) in the three seasons, while lettuce plantations alone and lettuce intercropping, with onion and with garlic were recorded in February in 2015 and 2016 but it was in March in 2017 season. Also, the highest monthly average number of Monacha spp. were recorded in March on lettuce plantations alone and followed by lettuce intercropping, with onion and garlic, while garlic plantations alone, garlic (intercropped, with lettuce) and onion plantations alone and onion (intercropped, with lettuce) were recorded in February or March. It can be noticed that, Monacha spp. was the high attractive to lettuce, while garlic and onion were the least attractive during the three successive seasons. The population abundance of thrips and snails differed according to host plant, there were significant differences among host plants $(\mathrm{p} \leq 0.05)$. The rate of infestation was higher in the sole crops than in those intercropped crops which caused reduction of T. tabaci and Monacha spp., and almost, significant differences were found $(\mathrm{p} \leq 0.05)$.The resultant yield, due to intercropping, was also affected. The lettuce, onion and garlic plants intercroppe reduced the resultant yield when compared with control.

Keywords: Lettuce, onion, garlic, population, intercropping, thrips, land snail.

\section{INTRODUCTION}

Common lettuce, Lactuca sativa $\mathrm{L}$. is native to the Mediterranean area and was domesticated in Egypt around 4,500 B.C. (Kerns et al., 2001). Onion (Allium cepa L.) is one of the most popular and important vegetables for fresh and dry consumption with Egypt production in the year 2012-13 reached 2.30 million tones (FAO, 2014). Garlic (Allium sativum L.) is one of the main important bulbous vegetable crops grown in Egypt for local consumption and exportation and is next to onion in importance (Hamma et al., 2013).

Thrips tabaci (Thysanoptera: Thripidae) were found to be widely distributed on onion and garlic crops and were important insect pests of the crops causing direct and indirect damage which result in yield reduction (Zsofia and Adam, 2012, Paibomesai and McDonald-Muck, 2013 and Zereabruk, 2017). Workman et al. (2007) and ELFakharany and Hendawy (2012) found that onion thrips was the dominant thrips species on lettuce, they concluded that the low numbers of thrips on lettuce and the low rates of reproduction indicate that lettuce is a poor host plant. Abd El-Wahed (2014) and Samy et al. (2015) mentioned that land snails, Monacha spp. (Gastropoda: Hygromiidae) attack lettuce and onion plants.

The intercropping between some crops is recommended in some cases as one of agricultural practices to achieve integrated pest management (IPM). So, many authors studied its positive and negative effects on the infestation rates of the pests (Trdan et al., 2006 and Metwally et al.,2008). Afifi et al. (1990) reported 80\% reduction in onion thrips infestation by intercropping of onions and garlic with tomato in Egypt. Also, with Gachu et al. (2012) who observed up to $45.2 \%$ and $21.6 \%$, reduction of onion thrips density when onion crop was intercropped with spider plant and carrot, respectively. Khaliq et al. (2016) found that onion thrips population reduction when onion was intercropped with cotton, tomato, chili and okra, as compared to control.
The objective of this study was to investigate the effect of different host plants on the population abundance of the onion thrips, Thrips tabaci Lind. and the land snail, Monacha spp. according to intercropping some vegetable crops and the final yield of those crops.

\section{MATERIALS AND METHODS}

1. Effect of different host plants and intercropping on the population of Thrips tabaci and Monacha spp.

For studying the effect of different host plants on the population abundance of the onion thrips, Thrips tabaci Lind. and the land snail, Monacha spp. according to intercropping some vegetable crops and the final yield of those crops., a field experiment was conducted at El-Riad district, Kafr El-Sheikh governorate during three successive years, 2014/15, 2015/16 and 2016/17. The lettuce, Lactuca sativa L. cultivar, Roman, onion (Allium cepa L.) cultivar, Buheirah red and garlic (Allium sativum L.) cultivar, (sids 40). The experimental area was about one feddan divided into four plots, each crop was represented by four replicates arranged in a complete randomized block design were weekly inspected randomly. Garlic lobes were sown on October, 20 and onion seedlings were planted on December, 10, while lettuce seedlings were transplanted on December, 27 (The crop was grown with the other crop in alternating rows). Those sole crops were planted at the same time of its intercropping date. Inspection started on January 17 and continued weekly till March 28 of each season. Number of snails was counted $3 \mathrm{~m}^{2} /$ replicate in the field, while thrips was counted 10 plants/replicate.

\section{Effect of intercropping on weight production}

Impact of the used intercropping on the weight of the final crop production was evaluated. Final total yield was taken from one plot $\left(3 \mathrm{~m}^{2}\right), 4$ times for each treatment. 3. Statistical analysis

Pests were evaluated for differences between vegetable crops using analysis of variance (ANOVA). Significant differences between the means of these crops were calculated by Duncan's Multiple Rang Test (Duncan 1955). 


\section{RESULTS AND DISCUSSION}

1. Effect of different host plants and intercropping on the population abundance

The onion thrips, Thrips tabaci Lind.

Data in Table (1) showed that, the highest monthly average number of $T$. tabaci during the first season, 2015 were recorded in March on onion alone represented by 456.75 individual/10 plants followed by onion intercropping, with lettuce (402.94). Also, garlic alone and garlic (intercropped with lettuce) were recorded in March represented by 209.63 and 180.75 , respectively. While lettuce alone and lettuce intercropping, with onion and with garlic were recorded in February with 72.38, 55.31 and 45.31 respectively. The high population abundance of thrips was observed in onion plantations alone (240.75) followed by onion (intercropped with lettuce) (190.40) and garlic alone (106.75) when compared with lettuce plantations alone (47.15). The rate of infestation was higher in the sole crops plants than in those intercropped with lettuce, onion and garlic which caused reduction of $T$. tabaci in 2015 season (Table 1).

Statistical analysis revealed that, almost each of seven treatments differed significantly with thrips infestation among vegetable crops $(\mathrm{p} \leq 0.05)$ (Table 1$)$.

Table 1. Monthly average number of Thrips tabaci in different host plants according to intercropping during season, 2014/15 at Kafr El-Sheikh governorate

\begin{tabular}{lcccc}
\hline Host plant & \multicolumn{4}{c}{ Mean no. of Thrips tabaci/10 plants \pm SE* } \\
\cline { 2 - 5 } & January & February & March & Mean \\
\hline Lettuce only & $8.83 \pm 5.31$ & $72.38 \pm 10.57$ & $60.25 \pm 13.70$ & $47.15 \pm 15.92 \mathrm{~d}$ \\
Onion only & $30.0 \pm 6.92$ & $235.5 \pm 24.97$ & $456.75 \pm 23.70$ & $240.75 \pm 100.72 \mathrm{a}$ \\
Garlic only & $20.0 \pm 0.47$ & $90.63 \pm 29.86$ & $209.63 \pm 30.25$ & $106.75 \pm 45.23 \mathrm{c}$ \\
\hline Lettuce with onion & & & & \\
Lettuce & $3.75 \pm 2.13$ & $55.31 \pm 15.18$ & $38.13 \pm 5.03$ & $32.40 \pm 12.39 \mathrm{~d}$ \\
Onion & $22.0 \pm 6.12$ & $146.25 \pm 49.54$ & $402.94 \pm 38.77$ & $190.40 \pm 91.69 \mathrm{~b}$ \\
\hline Lettuce with garlic & & & \\
Lettuce & $5.67 \pm 3.84$ & $45.31 \pm 9.93$ & $33.94 \pm 4.49$ & $28.31 \pm 8.33 \mathrm{~d}$ \\
Garlic & $12.75 \pm 1.85$ & $63.94 \pm 20.55$ & $180.75 \pm 31.14$ & $85.81 \pm 40.64 \mathrm{c}$ \\
\hline In a column, means followed by the same letter are not significantly different at the 5\% level by Duncan (1955) & *Standard error
\end{tabular}

Also, data in Table (2) showed that, the highest monthly average number of T. tabaci in the second 2016 season on onion plantations alone with 370.13 individual/10 plants followed by onion (intercropped with lettuce) (279.38) were recorded in March. Garlic plantations alone and garlic intercropping with lettuce) were recorded in March represented by 186.25 and 130.0 respectively, while lettuce plantations alone and lettuce (intercropped with onion and with garlic) were recorded in February represented by 56.94, 33.44 and 32.44, respectively. The high population abundance of thrips was observed in onion plantations alone (158.77) followed by onion (intercropping, lettuce with onion) (131.61) and garlic alone (95.15) when compared with lettuce plantations alone (34.52). The rate of infestation was higher in the sole crops plants than in those intercropped with lettuce, onion and garlic which caused reduction of $T$. tabaci in 2016 season (Table 2).

Statistical analysis revealed that, almost each of seven treatments differed significantly with thrips infestation among vegetable crops $(p \leq 0.05)$ (Table 2$)$.

Table 2. Monthly average number of Thrips tabaci in different host plants according to intercropping during season, 2015/16 at Kafr El-Sheikh governorate

\begin{tabular}{lcccc}
\hline \multirow{2}{*}{ Host plant } & \multicolumn{4}{c}{ Mean no. of Thrips tabaci/10 plants \pm SE* } \\
\cline { 2 - 5 } & January & February & March & Mean \\
\hline Lettuce only & $3.92 \pm 0.84$ & $56.94 \pm 14.52$ & $42.69 \pm 2.46$ & $34.52 \pm 12.95 \mathrm{e}$ \\
Onion only & $12.5 \pm 2.56$ & $93.69 \pm 14.70$ & $370.13 \pm 30.71$ & $158.77 \pm 88.49 \mathrm{a}$ \\
Garlic only & $16.33 \pm 0.56$ & $82.88 \pm 26.90$ & $186.25 \pm 26.56$ & $95.15 \pm 40.41 \mathrm{c}$ \\
\hline Lettuce with onion & & & & \\
Lettuce & $1.33 \pm 0.56$ & $33.44 \pm 6.85$ & $33.38 \pm 1.93$ & $22.72 \pm 8.74 \mathrm{e}$ \\
Onion & $8.33 \pm 1.31$ & $107.13 \pm 33.83$ & $279.38 \pm 30.63$ & $131.61 \pm 64.74 \mathrm{~b}$ \\
\hline Lettuce with garlic & & & & \\
Lettuce & $0.83 \pm 0.49$ & $32.44 \pm 9.43$ & $24.56 \pm 2.13$ & $19.28 \pm 7.77 \mathrm{e}$ \\
Garlic & $8.0 \pm 1.42$ & $56.75 \pm 19.41$ & $130.0 \pm 22.83$ & $64.92 \pm 28.98 \mathrm{~d}$ \\
\hline In a column, means followed by the same letter are not significantly different at the 5\% level by Duncan (1955) & *Standard error
\end{tabular}

Results in Table (3) showed that, the highest monthly average number of T. tabaci in 2017 season were recorded in March on onion plantations alone represented by 585.38 individual $/ 10$ plants followed by onion intercropping with lettuce (436.75). Also, garlic plantations alone and garlic (intercropped with lettuce) were recorded in March by 263.0 and 198.38, respectively, also lettuce alone and lettuce intercropping, with onion and garlic were recorded in March with 59.75, 40.88 and 37.5, respectively. The high population abundance of thrips was observed in onion plantations alone (236.54) followed by onion (intercropped with lettuce) (192.92) and garlic alone (128.25) when compared with lettuce plantations alone (37.54). The rate of infestation was higher in the sole crops plants than in those intercropped with lettuce, onion and garlic which caused reduction of T. tabaci in 2017 season (Table 3).

Statistical analysis revealed that, almost each of seven treatments differed significantly with thrips infestation among vegetable crops $(p \leq 0.05)$ (Table 3$)$. 
Table 3. Monthly average number of Thrips tabaci in different host plants according to intercropping during season, 2016/17 at Kafr El-Sheikh governorate

\begin{tabular}{lcccc}
\hline \multirow{2}{*}{ Host plant } & \multicolumn{4}{c}{ Mean no. of Thrips tabaci/10 plants \pm SE* } \\
\cline { 2 - 5 } & January & February & March & Mean \\
\hline Lettuce only & $3.67 \pm 1.57$ & $49.19 \pm 6.50$ & $59.75 \pm 4.38$ & $37.54 \pm 14.06 \mathrm{c}$ \\
Onion only & $17.0 \pm 3.86$ & $107.25 \pm 20.99$ & $585.38 \pm 60.93$ & $236.54 \pm 144.16 \mathrm{a}$ \\
Garlic only & $20.58 \pm 4.78$ & $101.18 \pm 37.51$ & $263.0 \pm 39.78$ & $128.25 \pm 58.27 \mathrm{c}$ \\
\hline Lettuce with onion & & & & \\
Lettuce & $1.0 \pm 0.62$ & $36.25 \pm 10.95$ & $40.88 \pm 5.61$ & $26.04 \pm 10.29 \mathrm{c}$ \\
Onion & $11.75 \pm 2.26$ & $130.25 \pm 47.31$ & $436.76 \pm 49.61$ & $192.92 \pm 103.51 \mathrm{~b}$ \\
\hline Lettuce with garlic & & & & \\
Lettuce & $1.25 \pm 0.66$ & $33.81 \pm 3.20$ & $37.5 \pm 13.01$ & $24.19 \pm 9.42 \mathrm{c}$ \\
Garlic & $12.33 \pm 4.71$ & $71.25 \pm 27.61$ & $198.38 \pm 27.95$ & $93.99 \pm 44.88 \mathrm{~d}$ \\
\hline In a column, means followed by the same letter are not significantly different at the 5\% level by Duncan (1955) & $*$ Standard error
\end{tabular}

As a conclusion, the population abundance of thrips differed according to host plant and T. tabaci was the high attractive to onion followed by garlic, while lettuce was least attractive during the three successive seasons. It can be noticed the highest monthly average number of $T$. tabaci were recorded in March on onion plantations alone and onion (intercropped with lettuce), followed by garlic plantations alone, garlic intercropping, with lettuce in the three seasons, while lettuce plantations alone and lettuce (intercropped with onion and garlic) were recorded in February in 2015 and 2016 but it was in March in 2017 season. The rate of infestation was higher in the sole crops plants than in those intercropped with lettuce, onion and garlic which caused reduction of $T$. tabaci in the three seasons. Almost, each of seven treatments differed significantly with infestation thrips among vegetable crops $(\mathrm{p} \leq 0.05)$.

These results are in agreement with those of Afifi et al. (1990) as they reported $80 \%$ reduction in onion thrips infestation by intercropping of onions and garlic with tomato in Egypt. Workman et al. (2007) found that thrips populations peaked in December to February with greatest numbers in February on lettuce. Hendawy et al. (2011) stated that the population density of T. tabaci peaked in February, March and April on onion plantations. EL-Fakharany and Hendawy (2012) found that T. tabaci was lower in October plantations than those of January plantations on lettuce. El-Fakharany et al. $\left(2012^{\mathrm{a}}\right)$ found that the population density of $T$. tabaci reached its maximum abundance at the second, third and fourth weeks of March on garlic plants. Gachu et al. (2012) who observed up to $45.2 \%$ and $21.6 \%$, reduction of onion thrips density when onion crop was intercropped with spider plant and carrot, respectively. Khaliq et al. (2016) found that onion thrips population reduction when onion was intercropped with cotton, tomato, chili and okra, as compared to control. Khan et al. (2017) found that $T$. tabaci was the dominant pest species on onion plantations. Zereabruk (2017) found that population density of thrips on onion plants was low in December and progressively increased to reach its maximum degree in March.

\section{The land snails, Monacha spp.}

Data in Table (4) showed that, the highest monthly average number of Monacha spp. during the first season, 2015 were recorded in March on lettuce plantations alone represented by 126.5 individual $/ 3 \mathrm{~m}^{2}$ followed by lettuce intercropping, with onion and garlic (96.19 and 91.19, respectively). Also, onion plantations alone and onion (intercropped with lettuce) were recorded in March by 14.31 and 7.25, respectively, while garlic plantations alone and garlic intercropping, with lettuce and were recorded in February with 15.31 and 9.06, respectively. The high population abundance of snails was observed in lettuce plantations alone (58.88) followed by lettuce (intercropped with onion and garlic) (43.92 and 41.63, respectively), while it was least on onion plantations alone (5.25), onion intercropping, with lettuce (2.5), garlic plantations alone (7.62) and garlic (intercropped with lettuce) (4.79).

Table 4. Monthly average number of Monacha spp. in different host plants according to intercropping during season, 2014/15 at Kafr El-Sheikh governorate

\begin{tabular}{|c|c|c|c|c|}
\hline \multirow{2}{*}{ Host plant } & \multicolumn{4}{|c|}{ Mean no. of Monacha spp. $/ 3 \mathrm{~m}^{2} \pm \mathrm{SE}^{*}$} \\
\hline & January & February & March & Mean \\
\hline Lettuce only & $1.0 \pm 0.82$ & $49.13 \pm 12.38$ & $126.5 \pm 14.63$ & $58.88 \pm 29.88 \mathrm{a}$ \\
\hline Onion only & $0.0 \pm 0.0$ & $1.44 \pm 0.58$ & $14.31 \pm 4.07$ & $5.25 \pm 3.72 \mathrm{c}$ \\
\hline Garlic only & $20.58 \pm 4.78$ & $15.31 \pm 6.06$ & $7.56 \pm 2.74$ & $7.62 \pm 3.61 \mathrm{c}$ \\
\hline Lettuce with onion & & & & \\
\hline Lettuce & $0.75 \pm 0.61$ & $34.81 \pm 9.58$ & $96.19 \pm 10.13$ & $43.92 \pm 22.83 \mathrm{~b}$ \\
\hline Onion & $0.0 \pm 0.0$ & $0.38 \pm 0.21$ & $7.25 \pm 1.72$ & $2.54 \pm 1.93 \mathrm{c}$ \\
\hline Lettuce with garlic & & & & \\
\hline Lettuce & $0.0 \pm 0.0$ & $33.69 \pm 12.05$ & $91.19 \pm 9.86$ & $41.63 \pm 21.76 \mathrm{~b}$ \\
\hline Garlic & $0.0 \pm 0.0$ & $9.06 \pm 4.83$ & $5.31 \pm 1.66$ & $4.79 \pm 2.1544 .88 \mathrm{c}$ \\
\hline
\end{tabular}

The rate of infestation was higher in the sole crops plants than in those intercropped with lettuce, onion and garlic which caused reduction of Monacha spp. in 2015 season (Table 4).
Statistical analysis revealed that, almost each of seven treatments differed significantly with land snail infestation among vegetable crops $(\mathrm{p} \leq 0.05)$ (Table 4$)$.

Also, data in Table (5) showed that, the highest monthly average number of Monacha spp. during the second season, 2016 were recorded in March on lettuce 
plantations alone represented by 211.5 individual $/ 3 \mathrm{~m}^{2}$ followed by lettuce intercropping, with onion and garlic) (159.06 and 147.75 respectively), while garlic plantations alone and garlic (intercropped with lettuce) and were recorded in February with 35.63 and 18.81, respectively also, onion plantations alone and onion (intercropped with lettuce) were recorded in February represented by 14.25 and 8.81 , respectively. The high population abundance of snails was observed in lettuce plantations alone (142.0) followed by lettuce intercropping, with onion and garlic) (105.60 and 90.69, respectively), while it was the least on onion plantations alone (7.88), onion (intercropped, with lettuce) (5.0), garlic plantations alone (16.31) and garlic intercropping, with lettuce) (8.71). The rate of infestation was higher in the sole crops plants than in those intercropped with lettuce, onion and garlic which caused reduction of Monacha spp. in 2015 season (Table 5).

Table 5. Monthly average number of Monacha spp. in different host plants according to intercropping during season, 2015/16 at Kafr El-Sheikh governorate

\begin{tabular}{lcccc}
\hline \multirow{2}{*}{ Host plant } & \multicolumn{4}{c}{ Mean no. of Monacha $\mathbf{~ S p p . ~} / \mathbf{3 m}^{2} \pm \mathbf{S E} *$} \\
\cline { 2 - 5 } & January & February & March & Mean \\
\hline Lettuce only & $6.75 \pm 5.52$ & $207.75 \pm 41.40$ & $211.5 \pm 64.13$ & $142.0 \pm 55.29 \mathrm{a}$ \\
Onion only & $0.0 \pm 0.0$ & $14.25 \pm 5.59$ & $9.38 \pm 2.08$ & $7.88 \pm 3.42 \mathrm{~d}$ \\
Garlic only & 0.75 & $35.63 \pm 21.14$ & $12.56 \pm 3.37$ & $16.31 \pm 8.37 \mathrm{~d}$ \\
\hline Lettuce with onion & & & \\
Lettuce & $6.5 \pm 5.31$ & $151.25 \pm 43.65$ & $159.06 \pm 29.26$ & $105.60 \pm 40.55 \mathrm{~b}$ \\
Onion & $0.0 \pm 0.0$ & $8.81 \pm 3.65$ & $6.19 \pm 1.38$ & $5.0 \pm 2.14 \mathrm{~d}$ \\
\hline Lettuce with garlic & & & \\
Lettuce & $6.0 \pm 4.90$ & $118.31 \pm 31.93$ & $147.75 \pm 31.55$ & $90.69 \pm 35.30 \mathrm{c}$ \\
Garlic & $0.0 \pm 0.0$ & $18.81 \pm 12.48$ & $7.31 \pm 1.92$ & $8.71 \pm 4.48 \mathrm{~d}$ \\
\hline In a column, means followed by the same letter are not significantly different at the 5\% level by Duncan (1955) & *Standard error
\end{tabular}

Statistical analysis revealed that, almost each of seven treatments differed significantly with land snail infestation among vegetable crops $(\mathrm{p} \leq 0.05)$ (Table 5).

The obtained results, in Table (6) showed that, the highest monthly average number of Monacha spp. in 2017 season, were recorded in March on lettuce plantations alone (594.56) followed by lettuce intercropping, with onion and garlic (451.0 and 421.13, respectively). Also, garlic plantations alone and garlic intercropping, with lettuce were recorded in March represented by 78.63 and 40.13 , respectively followed by onion plantations alone and onion (intercropped with lettuce) (41.81 and 26.06, respectively). The high population abundance of snails was observed in lettuce plantations alone (239.33) followed by lettuce (intercropped, with onion and garlic) (179.56 and 164.93, respectively), while it was the least on onion plantations alone (10.80), onion intercropping, with lettuce) (9.21), garlic plantations alone (35.1) and garlic intercropping, with lettuce (17.73). The rate of infestation was higher in the sole crops plants than in those intercropped with lettuce, onion and garlic which caused reduction of Monacha spp. in 2017 season (Table 6).

Table 6. Monthly average number of Monacha spp. in different host plants according to intercropping during season, 2016/17 at Kafr El-Sheikh governorate

\begin{tabular}{|c|c|c|c|c|}
\hline \multirow{2}{*}{ Host plant } & \multicolumn{4}{|c|}{ Mean no. of Monacha spp. $/ 3 \mathrm{~m}^{2} \pm \mathrm{SE}^{*}$} \\
\hline & January & February & March & Mean \\
\hline Lettuce only & $3.75 \pm 3.07$ & $119.69 \pm 6.50$ & $594.56 \pm 133.46$ & $239.33 \pm 147.75 \mathrm{a}$ \\
\hline Onion only & $0.08 \pm 0.07$ & $4.63 \pm 1.80$ & $41.81 \pm 15.33$ & $15.51 \pm 10.80 \mathrm{c}$ \\
\hline Garlic only & $0.42 \pm 0.34$ & $26.25 \pm 7.98$ & $78.63 \pm 24.5$ & $35.1 \pm 18.81 \mathrm{c}$ \\
\hline Lettuce with onion & & & & \\
\hline Lettuce & $3.42 \pm 2.79$ & $84.25 \pm 20.18$ & $451.0 \pm 84.80$ & $179.56 \pm 112.58 b$ \\
\hline Onion & $0.0 \pm 0.0$ & $1.56 \pm 0.55$ & $26.06 \pm 7.96$ & $9.21 \pm 6.90 \mathrm{c}$ \\
\hline Lettuce with garlic & & & & \\
\hline Lettuce & $1.67 \pm 1.36$ & $72.0 \pm 20.99$ & $421.13 \pm 89.04$ & $164.93 \pm 106.02 \mathrm{~b}$ \\
\hline Garlic & $0.0 \pm 0.0$ & $13.06 \pm 4.67$ & $40.13 \pm 18.09$ & $17.73 \pm 9.66 \mathrm{c}$ \\
\hline
\end{tabular}

In a column, means followed by the same letter are not significantly different at the $5 \%$ level by Duncan (1955) ～*Standard error

Statistical analysis revealed that, almost each of seven treatments differed significantly with Monacha spp.infestation among vegetable crops $(\mathrm{p} \leq 0.05)$ (Table 6).

As a conclusion, the population abundance of snails differed according to host plant and Monacha spp. was the high attractive to lettuce, while garlic and onion were the least attractive during the three successive seasons. It can be noticed the highest monthly average number of Monacha spp. were recorded in March on lettuce plantations alone followed by lettuce intercropping, with onion and garlic), while garlic plantations alone, garlic (intercropped with lettuce) and onion plantations alone and onion intercropping, with lettuce) were recorded in February or March. The rate of infestation was higher in the sole crops plants than in those intercropped with lettuce, onion and garlic which caused reduction of Monacha spp. in the three seasons. The intercropping between some crops is an important element in some cases as one of agricultural practices to achieve integrated pest management (IPM). Almost, each of seven treatments differed significantly with infestation Monacha spp. among vegetable crops $(\mathrm{p} \leq 0.05)$.

These results are in agreement with those of AbdelAal (2001) who reported that the population density of $M$. cartusiana increased during spring months. Shetaia et al. (2009) found that population dynamics of M. cartusiana snail was high at the tested winter crops (egyptian clover, faba bean, pea, lettuce and cabbage) during spring months as compared with winter or autumn months. Abd ElWahed (2014) encountered high population density of 
Monacha spp. on pea, lettuce and cabbage than in carrot and potatoes plantations. Samy et al. (2015) found that population densities of Monacha spp. were lower in onion plantations than in lettuce and cabbage plantations.

\section{Effect of intercropping of lettuce, onion and garlic on net weight production}

During 2014/15, 2015/16 and 2016/17, the resultant yield, due to intercropping, was also affected. This intercropping for lettuce, onion and garlic reduced the resultant yield of lettuce (intercropped with onion) (1.38\%), lettuce intercropping, with garlic $(2.21 \%)$, onion intercropping, with lettuce $(1.75 \%)$ and garlic (intercropped, with lettuce) $(2.19 \%)$ in the three seasons (Table 7).

Table 7. Effect of intercropping on net weight production

\begin{tabular}{|c|c|c|c|c|c|}
\hline \multirow[t]{2}{*}{ Host plant } & \multicolumn{3}{|c|}{ 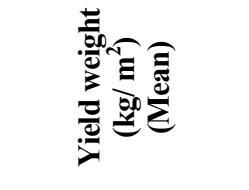 } & \multirow[t]{2}{*}{ 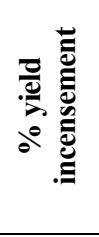 } & $\begin{array}{l}\text { Yield weight } \\
\text { (ton/feddan) }\end{array}$ \\
\hline & 2015 & 2016 & 2017 & & $\begin{array}{lll}2015 & 2016 & 2017\end{array}$ \\
\hline ly & & 3.62 & & .0 & 5.461 \\
\hline & 3.01 & 3.10 & 3.03 & & 12.6413 \\
\hline arlic only & 2.75 & 2.65 & 2.82 & .0 & 1.551 \\
\hline \multicolumn{6}{|c|}{ Lettuce with onion } \\
\hline Lettuce & 3.63 & 3.58 & 3.48 & -1.38 & 15.2515 \\
\hline nion & 2.95 & 3.04 & 2.99 & & 2.391 \\
\hline \multicolumn{6}{|c|}{ Lettuce with garlic } \\
\hline ettuce & 3.58 & 3.55 & 3.47 & -2.21 & 15.04 \\
\hline & 2.72 & 2.58 & 2.74 & -2.19 & 11.42 \\
\hline \multicolumn{6}{|c|}{$\begin{array}{l}\text { et al. (2006) also obtained similar results of thrips } \\
\text { suppression and higher onion bulb yield when onion } \\
\text { intercropped with white clover, but Lacy phacelia } \\
\text { intercropped in onion reduced onion yield. Similarly, } \\
\text { Kabura et al. (2008) revealed that onion and pepper } \\
\text { intercropping did not affect bulb size. They also recorded } \\
\text { higher total and marketable onion yield in monocrop onion } \\
\text { than intercrop. El-Fakharany et al. ( } 2012^{b} \text { ) found that the } \\
\text { sugar beet plants intercropped with faba bean gave the } \\
\text { highest root yield. In the contrary, the intercropping with } \\
\text { maize and cabbage plants reduced the resultant yield. } \\
\text { Gombac and Trdan (2014) also found least thrips damage } \\
\text { to leek plants when intercropped with birds foot trefoil } \\
\text { (Lotus corniculatus L.) but significantly lower yield was } \\
\text { obtained as the intercrop remained pretty competitive } \\
\text { with leek plants. Khaliq et al. (2016) found that to reducing } \\
\text { thrips population, in the onion plots intercropped with } \\
\text { chili, okra, tomato also showed positive effects on } \\
\text { onion yield. }\end{array}$} \\
\hline
\end{tabular}

\section{REFERENCES}

Abd El-Aal, S. M. (2001). Studies on certain land snails at Sharkia Governorate. M. Sc. Thesis, Fac. Agric. Zagazig. UNiv., 137pp.

Abd El-Wahed, S. I. M. (2014). Biological and pathological studies on some land snail species and their control at Kafr El- Sheikh Governorate. M.Sc. Thesis, Fac. Science, Tanta Univ., 149 pp.
Afifi, F.M.L., M.F. Haydar and H.I.H. Omar (1990). Effect of different intercropping systems on tomato infestation with major insect pests, Bemisia tabaci Genn. (Hemiptera: Aleyrodidae), Myzus persicae Sulzer (Homoptera: Aphididae) and Phthorimaea operculella Zeller (Lepidoptera: Gelechiidae). Bull. Fac. Agric., Uni. Cairo, 41: 885-900.

Duncan, B. D. (1955). Multiple range and multiple F test. Biometrics 11:1-42.

EL-Fakharany, S. K. M. and A. S. Hendawy (2012). Survey and population fluctuations of arthropod pests and natural enemies in lettuce plantations at Kafr El-Sheikh Governorate. Bull. Ent. Soc. Egypt, Econ. Series, 89: 87-102.

El-Fakharany, S. K. M., M. A. Samy and A. S. Hendawy $\left(2012^{\mathrm{a}}\right)$. Population fluctuations of Thrips tabaci Lindeman and associated spiders in garlic plantations as influenced by weather factors and toxic compounds. Egypt J.Agric. Res., 90(2/1):1-15.

El-Fakharany, S.K.M., M. A. Samy, S.A. Ahmed and M.A. Khattab $\left(2012^{b}\right)$. Effect of intercropping of maize, bean, cabbage and toxicants on the population levels of some insect pests and associated predators in sugar beet plantations. The Journal of Basic \& Applied Zoology, 65: 21-28.

FAO, (2014). Major food and agricultural commodities and producers-countries by commodity". Food and Agriculture Organization of the United Nations. www. Fao. org.

Hamma, I. L., U.1. Ibrahim and A. B. Mohammed (2013). Growth, yield and economic performance of garlic (Allium sativum L.) as influenced by farm yard manure and spacing in Zaria, Nigeria. J. Agric. Economics and Development 2(1): 1-5.

Hendawy, A. S., S. K. M. El-Fakharany and S. A. A. Kassem (2011).Ecological and toxicological studies on Thrips tabaci Lindeman and associated spiders on onion plantations. Egyptian J. Biolog. Pest Control, 21(2): 337-342.

Gombac, P. and S. Trdan (2014). The efficacy of intercropping with birds foot trefoil and summer savoury in reducing damage inflicted by onion thrips Thrips tabaci, (Thysanoptera: Thripidae) on four leek cultivars. J. Pl. Dis. Prot., 1213: 117-124

Kabura, B.H., B. Musa and P. E. Odo (2008). Evaluation of the yield components and yield of onion, Allium cepa L. and pepper, Capsicum annum L. intercrop in the Sudan savanna. J. Agron., 7: 88-92.

Kerns, D. L., M. E. Matheron, J. C. Palumbo, C. A. Sanchez, D. W. Still, B. R. Tickes, K. Umeda and M. A. Wilcox (2001). Guidelines for Head Lettuce Production in Arizona. IPM Series Number 12. Publication number az1099. Cooperative Extension, College of Agriculture and Life Sciences, University of Arizona, Tucson, Arizona.

Khaliq, A., M. Afzal, A. A. Khan, A. M. Raza, M. Kamran, H. M. Tahir, M. A. Aqeel and M. I. Ullah (2016). Management of Thrips tabaci (Thysanoptera: Thripidae) through agronomic practices in onion field plots. Pakistan J. Zool., 48(6):1675-1680. 
Khan, A. B., W. A. Panhwar, S. A. Mehmood, A. A. Gilal, S. Ahmed and Halimullah (2017). Population of Thrips tabaci Lindeman, 1889 in onion crop from district Mansehra, Khyber Pakhtunkhwa, Pakistan. J. Entomol. Zool. Studies, 5(4): 502-505.

Metwally, M. A. S., M. E. El-Naggar, H. M. El-Khateeb and A. M. M. Abou-Zaid (2008). Effect of intercropping of some aromatic plants on the infestation levels of Tetranychus urticae Koch to cucumber plants and its resulted yield in both open and greenhouse conditions. Egypt, J. Agric. Res., 86(1):259-268.

Paibomesai, M. and M. R. McDonald-Muck (2013). Onion thrips management-Part I; identification and monitoring. Ministry of Agriculture and Food, Ontario, Canada.

Samy, M. A., S. K. M. El-Fakharany and A. S. Hendawy (2015). Population fluctuation and host preference of land snail, Monacha spp. and its control of biocides compared with Neomyl. Egypt. J. Agric. Res., 93(1):93-106.

Shetaia, S. Z. S., S. A. A. Ismail and S. M. Abdel-Kader (2009). Survey, population dynamics and importance value of certain land snail species infesting different crops in Sharkia Governorate, Egypt. Acad. J. Biolog. Sci., 1 (1): 37-43.
Trdan, S., D. Znicdarcic, N. Valic, L. Rozman and M. Vidrih (2006). Intercropping against onion thrips, Thrips tabaci Lindeman (Thysanoptera: Thripidae) in onion production: on the suitability of orchard grass, Lacy phacelia, and buckwheat as alternatives for white clover. J. Pl. Dis. Prot., 113: 24-30.

Workman, P. J., G. P. Walker and S.Winkler (2007). Incidence and control of thrips on outdoor lettuce at Pukekohe. New Zealand Plant Protection, 60:42-49.

Zereabruk, G. (2017). Seasonal distribution and abundance of thrips (Thysanoptera: Thripidae) on onion production in central zone of Tigray, Ethiopia. Int. J. Life Sci., 5 (3): 323-331.

Zsofia, S. and B. Adam (2012). Manage onion thrips. Great lakes fruit, vegetable and farm market expo. 2011 in Grand Rapids at Michigan, State University.

\footnotetext{
تأثير اختلاف العائل النباتى والتحميل على الكثافة العددية لحشرة تربس البصل وThrips tabaci Lindeman

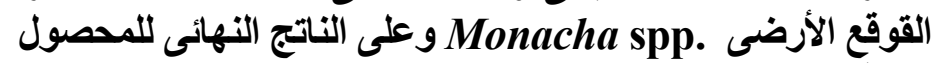

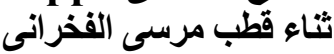

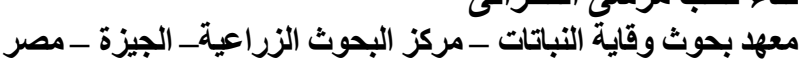

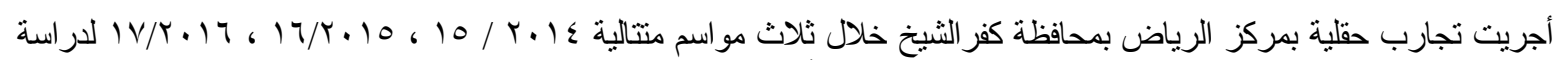

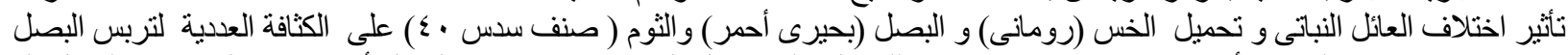
و و القوقع الأرضى .Monacha spprips tabaci

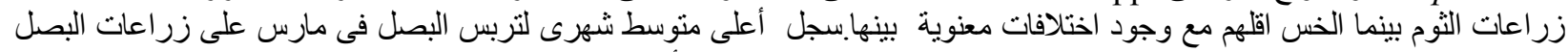

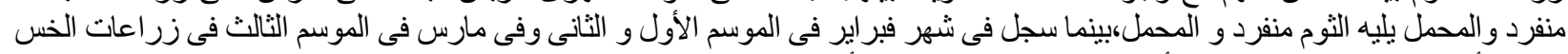

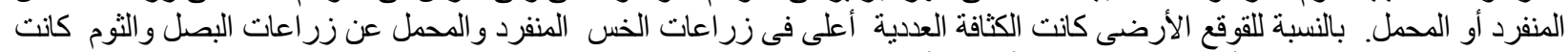

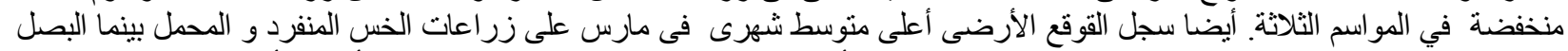

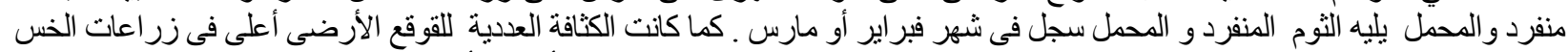

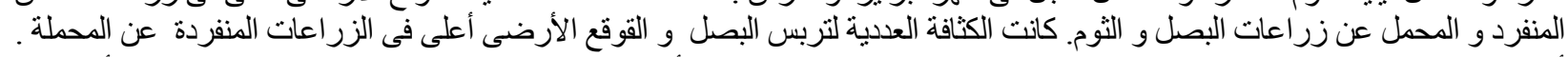

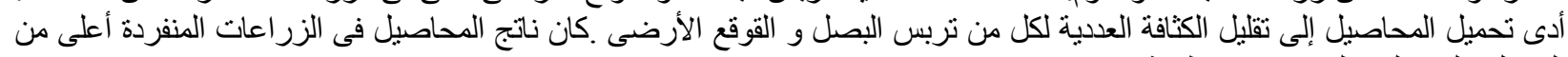
المحمل عليها ولكن الفروق كانت طفيفة جدا .
} 